\title{
One size fits nobody: En casestudie av yrkesfaglæreres deltakelse i kompetanse- utviklingsarbeid i videregående skole
}

\author{
(One size fits nobody: A case study of vocational education and \\ training teachers' participation in professional development projects \\ in upper secondary school)
}

\section{Julie Klovholt Leonardsen}

\author{
NTNU Norges teknisk-naturvitenskaplige universitet, Norge \\ (julie.leonardsen@ntnu.no)
}

\begin{abstract}
Vocational education and training (VET) teachers have a dual profession as teachers and vocational workers. Professional development projects in school must apply to both sides of their profession. However, VET teachers' need for professional development, particularly in terms of student assessment, has not been significantly explored. This ethnographic case study examines what aspects of professional development projects VET teachers perceive as meaningful for developing their assessment literacy. Data was collected through observations of 31 VET teachers in two upper secondary schools, in the context of a professional development project aiming to strengthen assessment literacy. Eighteen of these teachers also participated in focus group interviews. Findings show that if VET teachers are to find professional development projects in school meaningful for developing their assessment literacy, the projects must 1) have vocational relevance, 2) maintain a vocational perspective on the validity of assessment of students' vocational competence, and 3) take place in a learning and development-oriented culture. Unfortunately, professional development projects do not address teachers' developmental needs due to tensions among professional, socio-cultural and organisational contexts in school and vocational workplaces.
\end{abstract}

Keywords: vocational education and training teacher, dual professionalism, professional development, assessment, assessment literacy 


\section{Innledning}

Yrkesfaglærere er både fagarbeidere og lærere. Disse rollene representerer ulike syn på kunnskap og er forankret i henholdsvis arbeidslivets og skolens tradisjoner for læring (Andersson \& Köpsén, 2015; Fejes \& Köpsén, 2014). Yrkesfaglæreres doble profesjonalitet blir imidlertid ikke godt nok ivaretatt i norsk skole, spesielt i kompetanseutviklingsarbeid. Det skyldes blant annet at: 1) yrkesfaglæreres kompetanseutviklingsbehov er lite utforsket og dermed underkommunisert, 2) at politisk initierte kompetanseutviklingsstrategier for lærere i videregående opplæring ofte er forlengelser av prosjekter designet for grunnskole og 3) at begrepet "yrkesfag" brukes som samlebetegnelse for all yrkesutdanning i videregående skole og undergraver de enkelte yrkers autonomi (Aspøy mfl., 2017; Gjerustad \& Waagene, 2015; Høst mfl., 2015; Aamodt mfl., 2016).

Videregående opplæring i Norge omfatter både yrkesfaglige og studiespesialiserende utdanningsprogram. Begge kan gi studiekompetanse. Denne konstruksjonen skiller seg fra mange andre lands organisering av videregående opplæring, ettersom yrkesopplæring ikke nødvendigvis ligger innenfor den videregående opplæringens ansvarsområde (Aspøy mfl., 2017; Høst, 2015; Aamodt mfl., 2016). Det er derfor ingen selvfølge at hverken internasjonale eller nasjonale kompetanseutviklingstrender for grunnskole eller videregående kan overføres til norsk yrkesopplæring. Eksempelvis var den internasjonale "Assessment for learning"-satsningen, der The Assessment Reform Group i 1998 løftet frem formativ vurdering som avgjørende for elevers læring, i hovedsak designet for skoleslag uten yrkesfag (Assessment Reform Group, 2002). Kunnskapsdepartementet og Utdanningsdirektoratet lånte denne satsningen, døpte den "Vurdering for læring" og satte læreres kompetanseutvikling i læringsfremmede vurdering på dagsordenen i norsk skole (Eggen, 2011; Engh, 2011; Throndsen mfl., 2009). Satsningen tok imidlertid ikke høyde for at norske yrkesfaglærere har andre behov for kompetanseutvikling enn sine kolleger som underviser i tradisjonelle, akademiske skolefag.

I denne etnografiske casestudien trer jeg inn i et halvannet år langt skolebasert kompetanseutviklingsprosjekt ved to videregående skoler. Tema for prosjektet er utvikling av vurderingskompetanse i skolen, både på individuelt og kollektivt nivå. Datamaterialet bygger på observasjon av 31 yrkesfaglæreres utviklingsarbeid, der de i grupper utforsker egen vurderingskompetanse og -praksis. Jeg har også gjennomført fokusgruppeintervju med 18 av lærere. Forskningsspørsmålet er som følger: Hvilke aspekter ved kompetanseutviklingsprosjekter i videregående skole opplever yrkesfaglærere som meningsfulle for utvikling av egen vurderingskompetanse? 


\section{Bakgrunn og teoretisk forankring}

\section{Vurderingskompetanse}

Begrepet assessment literacy (AL) ble først benyttet av Stiggins $(1991,1995)$ for å beskrive læreres kunnskap om vurdering, samt hvordan de anvendte kunnskapen i praksis for å måle elevers prestasjoner. Tidlig forskning på AL var opptatt av læreres evne til å vurdere validiteten på dataene de la til grunn for vurderingsresultater, og hvordan de avdekket eventuelle feilkilder (Messick, 1992; Stiggins, 1991). Videre fattet vurderingsforskning interesse for hvordan ulike faglige, sosiale og organisatoriske kontekster kan påvirke læreres vurderingskompetanse og -praksiser (Brown, 2004; Popham, 2009; Taylor, 2009). Litteratur på feltet argumenterer for at læreres erfaringer med og antakelser om vurdering er betydningsfulle for hvordan de forstår vurderingsterminologi og teoretiske konsepter, samt hva de oppfatter som relevant og valid vurdering (DeLuca \& Klinger, 2010; DeLuca mfl., 2019; Looney mfl., 2018; Taylor, 2009).

Tradisjonelt har lærere stått alene i vurderingsarbeid og har måttet stole på sin egen dømmekraft i avgjørelser knyttet til vurdering (DeLuca, 2012; DeLuca mfl., 2013; Klenowski \& Wyatt-Smith, 2014). Nyere trender i både vurderings- og skoleutviklingsforskning viser imidlertid at deltakelse i tolknings- og vurderingsfellesskap i skolen kan ha positiv effekt på både læreres individuelle og skolens kollektive utvikling av vurderingskompetanse (Cochran-Smith \& Lytle, 2009; Eggen, 2011; Engh, 2011).

Validitetsbegrepet står sentralt i vurderingslitteratur. Det viser tradisjonelt til prosessen der eksempelvis en lærer samler og analyserer datamateriale (bevis) for å underbygge et resultat (Kane, 2015; Messick, 1992; Popham, 2009; Stiggins, 1991, 1995). Et utvidet validitetsbegrep tar også høyde for den sosiale og kulturelle sammenhengen vurderingen foregår i (Kane, 2015; Messick, 1992; Moss mfl., 2006). Forskning argumenterer for at vurderingssituasjoner i yrkesfagene bør være autentiske og ha relevans for fremtidig yrkesutøvelse (Aarkrog \& Wahlgren, 2015; Gills \& Bateman, 1999; Räisänen \& Räkköläinen, 2014). Denne tankegangen kan koples til både et utvidet validitetsbegrep og et økologisk validitetsperspektiv, der overførbarheten fra den situerte testsituasjonen til den virkelige verden står sentralt (Lewkowicz, 2001; Moss, 2013; Schmuckler, 2001).

AL har utviklet seg fra å omfatte lærerens kunnskap om testteoretiske aspekter ved vurdering (Messick, 1992; Stiggins, 1991) til å bli ansett som en integrert del av lærerens profesjonalitet (Black \& William, 1998, 2009; DeLuca mfl., 2013; Looney mfl., 2018; Popham, 2009; Xu \& Brown, 2016). I en omfattende konseptualisering av begrepet AL argumenterer Xu og Brown (2016) for at lærerens 1) fag-didaktiske og pedagogiske kunnskapsbase, 2) tolkning og forståelse av normative rammeverk, 3) epistemologiske antakelser om læring og vurdering, 4) sosiokulturelle og institusjonelle kontekster, 5) vurderingspraksiser og 
6) læring/profesjonelle utvikling bidrar til en kontinuerlig (re)konstruksjon av læreres vurderingskompetanse og vurderer-identitet.

\section{Yrkesfaglæreres vurderingskompetanse}

En rekke yrkesfag forfekter tause, praktiske og erfaringsbaserte tradisjoner for læring og vurdering (Dewey, 1916; Dreyfus \& Dreyfus, 1986; Lave \& Wenger, 1991; Sennett, 2008). Forskning viser at yrkesfaglæreres vurderingskompetanse er forankret i deres yrkesfaglige kunnskapsbase, og i de faglige og sosiokulturelle tradisjonene for læring og vurdering disse yrkene representerer (Kemmis \& Green, 2013; Robson mfl., 2004; Sennett, 2008). Videre viser forskning at yrkesfaglærere i stor grad støtter seg til sin yrkesfaglige bakgrunn i møte med skolen og lærerrollen (Andersson \& Köpsén, 2015; Fejes \& Köpsén, 2014; Kemmis \& Green, 2013). Eksempelvis viser Fejes og Köpsén (2014) studie at fagarbeidere konstruerer en ny identitet som lærere når de forflytter seg mellom praksisfellesskap (arbeidsliv og skole) og roller (fagarbeider og lærer).

Skolen forventer at yrkesfaglærere har tilstrekkelig kunnskap om pedagogikk, yrkesdidaktikk, skolens kultur, skolens læringstradisjoner, utdanningspolitiske rammeverk og skolens organisering, samt at de kan anvende denne kunnskapen i undervisnings- og vurderingsarbeidet sitt (Fejes \& Köpsén, 2014; Grande mfl., 2014; Kemmis \& Green, 2013; Robson mfl., 2004). Flere forskningsrapporter fra NIFU og FAFO (Aspøy mfl., 2017; Gjerustad \& Waagene, 2015; Grande mfl., 2014; Høst mfl., 2015; Aamodt mfl., 2016) antyder imidlertid at det er utfordrende for yrkesfaglærere å være brobyggere mellom om arbeidsliv og skole, ettersom disse aktørene kan ha ulike interesser i fag- og yrkesopplæringen. Rapportene problematiserer blant annet at mange yrkesfaglærere mangler formell lærerutdanning og dermed møter lærerrollen uten annen kunnskap om skolen som opplæringsinstitusjon enn egne erfaringer fra tiden de selv var elever. Andre mangler solid erfaring fra yrkeslivet (Aspøy mfl., 2017; Aamodt mfl., 2016). Dette vitner om at yrkesfaglærere, i tillegg til å komme fra yrkesfaglige tradisjoner med andre syn på læring og vurdering enn det som står sentralt i skolen, ikke nødvendigvis er godt nok rustet til å møte skolens krav til vurderingskompetanse. Resultatene fra rapportene vitner også at det mangler gode tilbud (etter- og videreutdanning, kompetanseutviklingsprosjekter) som ivaretar yrkesfaglæreres behov for kompetanseutvikling i vurdering.

Forskning på yrkesfag har imidlertid begynt å utforske hvordan yrkesfaglæreren ved hjelp av sin doble profesjon kan bidra til å minske gapet mellom vurderingsspraksiser i bedrift og i skole. Eksempelvis har Sund, Nore og Vagle (2009) forsket på hvordan yrkesfaglæreren bruker yrkespedagogiske prinsipper i opplæring og vurdering. Sylte (2014) har undersøkt hvordan vurderingsverktøy med tydelige kjennetegn på måloppnåelse kan fremme yrkesrelevant opplæring, og Hiim (2020) har forsket på hva yrkeskompetanse er og hvordan denne typen kompetanse kan vurderes. Likevel er yrkesfaglærerens vurderingskompetanse et 
lite utforsket felt både i yrkesfag og i vurderingsforskning. Denne studien er et kunnskapsbidrag til feltet og undersøker hvilke aspekter ved utviklingsarbeid i skolen yrkesfaglærere opplever som meningsfulle i utviklingen av egen vurderingskompetanse.

\section{Forskningsdesign og metode}

Studien er designet som en etnografisk casestudie. Designet gir forskeren mulighet til å gå i dybden og gi detaljerte beskrivelser av et fenomen (Flyvbjerg, 2006; Ragin \& Becker, 1992), i dette tilfellet en gruppe yrkesfaglæreres kompetanseutvikling i vurdering. Forskningsdesignet er hensiktsmessig for denne studien ettersom det er fleksibelt og tillater forskeren å innhente nødvendige data gjennom hele forskningsprosessen. Etnografiske casestudier stiller imidlertid strenge krav til transparens dersom de skal fremstå som troverdige, nettopp fordi forskerens forståelse og fortolkning av datamaterialet har betydning for studiens resultater (Flyvbjerg, 2006; Ragin \& Becker, 1992).

\section{Kontekst}

Studiens kontekst var et skolebasert kompetanseutviklingsprosjekt med fokus på utvikling av individuell og kollektiv vurderingskompetanse (SKUV - skolebasert kompetanseutvikling i vurdering). Prosjektet var et samarbeid mellom oppdragsgiver (en fylkeskommune/skoleeier), tilbydere (lærerutdannere ved et universitet) og samtlige videregående skoler i fylket. Prosjektperioden strakk seg fra 2016-2020, og hver skole var deltakere i halvannet år. Lærerne ved deltakerskolene var av skoleeier pålagt å delta i prosjektet, men de hadde stor handlefrihet innenfor prosjektets rammer. Lærerne kunne selv velge å ta etterutdanning (følge skolens prosjektplan) eller videreutdanning (følge skolens prosjektplan og avlegge eksamen ved universitetet for å få studiepoeng på masternivå).

Prosjektet tok sikte på å oversette den samlede vurderingskompetansen i skolene til de ulike fagenes egenart, koble den til vurderingsteori og drøfte muligheter for læring og utvikling i organisasjonen (NTNU \& TRFK, 2017). I praksis innebar dette at lærergrupper (prosjektgrupper på 3-5 lærere) ved den enkelte skole undersøkte egen vurderingspraksis ved å analysere, prøve ut og evaluere ulike vurderingsmetoder, samt hvordan disse påvirket elevers læring. Gruppene utforsket etter egne ønsker metoder for å 1) utvikle valide vurderingspraksiser i yrkesfaglig fordypning og 2) styrke vurderingssamarbeid mellom skole og bedrift, eksempelvis ved å utvikle digitale loggsystem. Arbeidet pågikk både på tidspunkt satt av skolen og i lærernes planleggingstid. Lærergruppene presenterte resultatene fra utviklingsarbeidet sitt muntlig og skriftlig for tilbyderne, skoleledelsen og kollegene sine.

Denne studien er del av et større prosjekt, men datamaterialet er frittstående. SKUV-prosjektet er kun kontekst for studien. Jeg undersøker yrkesfaglæreres 
opplevelse av deltakelse i utviklingsprosjektet, ikke hva de foretar seg i selve prosjektet.

\section{Forskningsdeltakere}

Deltakerne i studien er 31 utvalgte yrkesfaglærere fra bygg- og anleggsfag, naturbruk og restaurant- og matfag. De arbeider ved to ulike videregående skoler som deltar i SKUV. Tabell 1 gir bakgrunnsinformasjon om de to skolene (skoleslag, størrelse, beliggenhet og yrkesfaglige program). Tabell 2 gir bakgrunnsinformasjon om yrkesfaglærerne som deltar i studien

Tabell 1. Beskrivelse av skolene.

\begin{tabular}{|l|l|l|l|l|}
\hline & Skoleslag & Størrelse & Beliggenhet & $\begin{array}{l}\text { Yrkesfaglige } \\
\text { utdanningsprogram }\end{array}$ \\
\hline Skole 1 & $\begin{array}{l}\text { Videregånde skole } \\
\text { med tre yrkesfaglige } \\
\text { studieretninger, på- } \\
\text { bygg til studiekom- } \\
\text { petanse og kompe- } \\
\text { tansetilbud for } \\
\text { voksne }\end{array}$ & $\begin{array}{l}\text { Om lag } 350 \text { elever } \\
\text { og } 80 \text { ansatte } \\
\text { hvorav 52 er pe- } \\
\text { dagogisk perso- } \\
\text { nal som driver } \\
\text { undervisning }\end{array}$ & $\begin{array}{l}\text { I periferien } \\
\text { av storby/ } \\
\text { grensa til } \\
\text { distrikt }\end{array}$ & $\begin{array}{l}\text { 1. } \\
\text { bygg- og } \\
\text { anleggsteknikk } \\
\text { naturbruk } \\
\text { teknologi- og } \\
\text { industrifag }\end{array}$ \\
\hline Skole 2 & $\begin{array}{l}\text { Videregånde skole } \\
\text { med to studiespesi- } \\
\text { aliserende og tre yr- } \\
\text { kesfaglige studieret- } \\
\text { ninger, samt påbygg } \\
\text { til studiekompe- } \\
\text { tanse }\end{array}$ & $\begin{array}{l}\text { Om lag 1000 ele- } \\
\text { ver og 180 an- } \\
\text { satte, hvorav 118 } \\
\text { er pedagogisk } \\
\text { personal som dri- } \\
\text { ver undervisning }\end{array}$ & $\begin{array}{l}\text { Sentralt i } \\
\text { storby }\end{array}$ & $\begin{array}{l}\text { 1. } \\
\text { helse- og oppvekst- } \\
\text { fag } \\
\text { elektrofag } \\
\text { restaurant- og } \\
\text { matfag }\end{array}$ \\
\hline
\end{tabular}

Informasjonen i tabell 1 er hentet fra skolenes offisielle hjemmeside, men av hensyn til personvern er hverken skolene eller nettsidene navngitt.

Forskningsdeltakerne måtte innfri følgende kriterier for å delta i studien: 1) ha fag- eller svennebrev, 2) påbegynt eller fullført yrkesfaglærerutdanning (YFL) eller praktisk-pedagogisk utdanning for yrkesfag (PPUY), og 3) være i minimum $80 \%$ stilling som yrkesfaglærer i videregående skole. De 18 lærere som deltok i fokusgruppeintervjuene måtte i tillegg ha 4) minimum to års erfaring som yrkesfaglærer, 5) undervist i yrkesfaglig fordypning og 6) praktisert vurdering av elevers yrkeskompetanse i både skole- og yrkeskontekst. Lærerne ble valgt fordi de har både yrkes- og lærerutdanning, samt at de representerer yrkesfag med sterke mesterlæretradisjoner der overføring av taus, erfaringsbasert kunnskap er et sentralt aspekt ved opplæringen og sertifiseringen av nye fagarbeidere. 
One size fits nobody

Tabell 2. Beskrivelse av forskningsdeltakerne.

\begin{tabular}{|l|c|c|l|l|}
\hline Fagretning & Tilhørighet & Antall & Kjønn & Alder \\
\hline $\begin{array}{l}\text { Bygg- og anleggs- } \\
\text { teknikk }\end{array}$ & Skole 1 & 6 & Kun menn & 31 til 57 år \\
\hline Naturbruk & Skole 1 & 13 & $\begin{array}{l}\text { Jevn blanding av } \\
\text { kvinner og menn }\end{array}$ & 27 til 63 år \\
\hline $\begin{array}{l}\text { Restaurant- og } \\
\text { matfag }\end{array}$ & Skole 2 & 12 & $\begin{array}{l}\text { Blanding, men klar over- } \\
\text { vekt av menn (9 menn, } \\
\text { 3 kvinner }\end{array}$ & $\begin{array}{l}27 \text { til } 64 \text { år (kun } \\
\text { to under 50) }\end{array}$ \\
\hline
\end{tabular}

\section{Posisjonering}

Etnografiske studier krever refleksivitet. På bakgrunn av studiens deskriptive og fortolkende karakter, samt det tette forholdet mellom deltakere og forsker, velger jeg, som er både forskeren og forfatteren, å tematisere egen forskersubjektivitet og omtale meg selv med personlig pronomen. Jeg identifiserer meg langt på vei med deltakerne ettersom jeg har yrkesfaglig bakgrunn fra restaurant- og matfag og undervisningserfaring fra yrkesfag i videregående skole. I tillegg har jeg lektorutdanning med master i språkfag, samt en mastergrad i lærerprofesjon og yrkesutøvelse. Jeg representerer både yrkesfag og akademia, men det var utvilsomt min yrkesfaglige bakgrunn som åpnet dører i møte med deltakerne. Utsagn som "ja, du veit jo hvordan det er i praksis", "du vet jo hva som er relevant for arbeidslivet" viser at yrkesfaglærerne opplevde meg som en alliert eller fortrolig som forstår utfordringene de møter i sin doble profesjon. Jeg har selv en flersidig rolle i studien og må forhandle mellom rollen som fagarbeider, lærer og forsker.

Skole 1 er min tidligere arbeidsplass og deltakerne derifra er tidligere kolleger. Den unike posisjonen som "insider" gir meg mulighet til å grave dypere i lærernes opplevelser knyttet til egen vurderingspraksis og utvikling av denne, samt kontekstualisere funnene. Posisjonen kan likevel være risikabel ettersom jeg vet, eller tror jeg vet, mer enn funnene faktisk forteller. Jeg involverte skole 2, som jeg på daværende tidspunkt ikke hadde forbindelser til, for å innhente data jeg ikke kunne tillegge "insider-kunnskaper". Gjennom min rolle som en av tilbyders ressurspersoner ved den respektive skolen tilegnet jeg meg likevel omfattende informasjon om skolens vurderingskultur.

\section{Etiske betraktninger}

Relasjonene mellom forsker, forskningsdeltakerne og miljøet der forskningen foregår kan skape spenninger gjennom forskningsprosessen. Det har jeg som forsker fått kjenne på kroppen. En etnografisk forsker gjør på et punkt i forskningen 
sin en rolleendring og går fra å være insider til å bli outsider. Denne handlingen kan ifølge Street (2002) oppleves svikefull av forskningsdeltakerne, ettersom forskeren går fra å være et betrodd medlem av fellesskapet, til å bruke innsiderkunnskapen sin i forskningsøyemed. Det vil nødvendigvis oppstå spenninger når forskeren fortolker og teoretiserer deltakernes praksisnære begrep gjennom analytiske grep og fremmedgjør deres forståelse av praksis (Geertz, 2000). Jeg som forsker har derfor ansvar for å fremstille deltakernes erfaringer som troverdige, også når jeg stiller kritiske spørsmål.

For å overholde forskningsetiske retningslinjer og prinsipper ble alle lærerne informert om hensikten med studien og samtykket til deltakelse, både i observasjons- og samtalegrupper, og som deltakere i fokusgruppeintervjuene. Lærerne ble forsikret om at deres handlinger og utsagn ble behandlet konfidensielt, og at de fremstilles anonymt i studien. Lærerne fikk tilbud om å lese skriftlige råutkast av analyse og resultater for å sikre at de gjenkjente mine tolkninger av observasjoner og samtaler. Få deltakere responderte på tekstutdragene de fikk tilsendt, og jeg valgte da å gjennomførte "member checking" ved å informere deltakerne om studiens resultater i en av våre mange gruppesamtaler (Creswell, 2007; Kvale mfl., 2015).

\section{Datainnsamling}

Datamaterialet ble samlet gjennom observasjoner, uformelle samtaler og fokusgruppeintervju. Tabell 3 viser metodene jeg benyttet, hvem av lærerne som deltok, tidsperspektivet, hvilke typer datamateriale som ble samlet inn og de ulike kontekstene datainnsamlingen foregikk $\mathrm{i}$.

Jeg samlet data gjennom deltakende observasjon ved fire faste milepæler i det halvannet år lange utviklingsprosjektet; 1) i planleggingsfasen, 2) under utprøving i praksis, 3) i analysearbeidet og 4) i ferdigstillingsfasen. Gruppene og jeg møttes også ved to obligatoriske aktiviteter der lærerne formidlet utviklingsarbeidet sitt til kollegiet. Møtene lot meg delta i samtaler med gruppene, inngå i samspill med dem, observere deres handlinger og fange opp deres språk og kultur. Jeg observerte dem i ulike kontekster, eksempelvis i gruppemøter (planlegging, analyse, refleksjon, teoretisering), under utprøving i klasserom, verksted, stall, uteområder eller kjøkken og ved formidling av eget arbeid til kollegiet.

Halvveis i prosjektperioden inviterte jeg 18 av de 31 yrkesfaglærerne til fokusgruppeintervju. Det ble totalt seks intervjuer, hver av dem med tre til fire lærere. Jeg spurte dem eksempelvis om hvordan de arbeidet for å utvikle egen vurderingskompetanse og hva de opplevde som viktig og meningsfullt i slike prosesser. Intervjuene ble gjennomført på lærernes arbeidsplass og hadde en varighet på om lag 35 minutter. Lærerne samtykket til at jeg tok opptak av intervjuene. 
Tabell 3. Oversikt over datamaterialet.

\begin{tabular}{|c|c|c|c|c|}
\hline Metode & Deltakere & Varighet & Type data & Kontekst \\
\hline $\begin{array}{l}\text { Deltakende } \\
\text { observasjon }\end{array}$ & 31 lærere & $\begin{array}{l}\text { 1,5 år } \\
\text { Minimum } 3 \text { ob- } \\
\text { servasjoner av } \\
\text { hver gruppe in- } \\
\text { nenfor faste mile- } \\
\text { pæler i prosjektet: } \\
\text { 1.Planlegging } \\
\text { 2.Utprøving } \\
\text { 3.Analyse } \\
\text { 4. Ferdigstilling }\end{array}$ & $\begin{array}{l}\text { Feltnotater } \\
\text { Beskrivelser av kon- } \\
\text { tekst, situajjoner, } \\
\text { hendelser, samtaler, } \\
\text { refleksjoner, lærernes } \\
\text { verbale og non-ver- } \\
\text { bale språk, oppføl- } \\
\text { gingsspørsmål fra } \\
\text { forskeren og forske- } \\
\text { rens egne refleksjoner }\end{array}$ & $\begin{array}{l}\text { Gruppene ble ob- } \\
\text { servert på egen } \\
\text { skole under de faste } \\
\text { milepælene i pro- } \\
\text { sjektet og under to } \\
\text { obligatoriske aktivi- } \\
\text { teter der lærerne } \\
\text { delte utviklingsar- } \\
\text { beidet sitt med kol- } \\
\text { legiet }\end{array}$ \\
\hline $\begin{array}{l}\text { Uformelle } \\
\text { samtaler } \\
\text { med lærer- } \\
\text { gruppene }\end{array}$ & $\begin{array}{l}31 \text { lærere } \\
9 \text { grupper } \\
\text { (numme- } \\
\text { rert 1-9) } \\
\text { med 3-4 } \\
\text { lærere i } \\
\text { hver }\end{array}$ & $\begin{array}{l}1,5 \text { år } \\
\text { Om lag } 15 \text { samta- } \\
\text { ler med hver } \\
\text { gruppe } \\
\text { Minst en samtale } \\
\text { med hver enkelt } \\
\text { lærer i forbindelse } \\
\text { med utprøving av } \\
\text { eget forsknings- } \\
\text { prosjekt }\end{array}$ & $\begin{array}{l}\text { Feltnotater } \\
\text { Beskrivelser av kon- } \\
\text { tekst, situajjoner, } \\
\text { hendelser, samtaler, } \\
\text { refleksjoner, lærernes } \\
\text { verbale og non-ver- } \\
\text { bale språk, oppføl- } \\
\text { gingsspørsmål fra } \\
\text { forskere og forske- } \\
\text { rens egne } \\
\text { refleksjoner }\end{array}$ & $\begin{array}{l}\text { Samtalene fant sted } \\
\text { i forbindelse med } \\
\text { observasjonene. I } \\
\text { utprøvingsfasen } \\
\text { prøvde lærerne ut } \\
\text { sine prosjekter i } \\
\text { praksis og deres } \\
\text { respektive elever } \\
\text { var til stede og en- } \\
\text { kelte elever deltok i } \\
\text { samtaler med fors- } \\
\text { keren }\end{array}$ \\
\hline $\begin{array}{l}\text { Fokus- } \\
\text { gruppe- } \\
\text { intervju }\end{array}$ & $\begin{array}{l}18 \text { av de } 31 \\
\text { lærerne } \\
6 \text { grupper } \\
\text { (numme- } \\
\text { rert 1-6) } \\
\text { med 3-4 } \\
\text { lærere i } \\
\text { hver }\end{array}$ & $\begin{array}{l}\text { Ett intervju per } \\
\text { gruppe, varighet } \\
35 \text { minutter }\end{array}$ & $\begin{array}{l}\text { Transkripsjoner av } \\
\text { lydopptak } \\
\text { Lærerne svarte på } \\
\text { spørsmål vedrørende } \\
\text { eget kunnskapssyn, } \\
\text { egne antakelser om } \\
\text { vurdering, vurde-- } \\
\text { ringspraksiser, rollen } \\
\text { som vurderer og } \\
\text { hvordan de arbeider } \\
\text { for å utvikle egen } \\
\text { vurderingskompe- } \\
\text { tanse }\end{array}$ & $\begin{array}{l}\text { Intervjuene ble } \\
\text { gjennomført på mø- } \\
\text { terom på lærernes } \\
\text { respektive arbeids- } \\
\text { plasser }\end{array}$ \\
\hline
\end{tabular}

\section{Dataanalyse}

Analyseprosessen hadde fem steg. Det første steget var å sortere feltnotatene i kronologisk rekkefølge etter prosjektets milepæler: 1) planlegging, 2) utprøving 
i praksis, 3) analysearbeid og 4) ferdigstilling for å skape et helhetlig bilde. Data fra de to aktivitetene, der lærergruppene formidlet resultater fra utviklingsarbeidet sitt til kollegiet, ble inkludert i de øvrige milepælene. Den første av de to aktivitetene ble inkludert i punkt 1, 2 eller 3, avhengig av hvor langt de respektive gruppene hadde kommet i prosessen. Den andre ble inkludert i punkt 4.

Det andre steget var å gjennomføre en tematisk innholdsanalyse for å kartlegge hvilke aspekter ved kompetanseutviklingsprosjektet yrkesfaglærerne opplevde som meningsfulle og eventuelt meningsløse for utvikling av egen vurderingskompetanse. Varianter av begrepene "meningsfullt" og "meningsløst" ble flere ganger brukt av forskningsdeltakerne for å beskrive hva de opplevde som nyttig (relevant for egen praksis og elevers fremtidige yrkesutøvelse) og unyttig (tidstyver som administrativt arbeid og fokus på skriftliggjøring) for utvikling av egen praksis. I fokusgruppeintervjuene sa lærerne eksempelvis at "det er meningsfullt å delta i utviklingsarbeid som oppleves relevant for yrket elevene skal ut i", at "det gir mening å benytte praksisnære teorier i forskning på egen praksis" og at "det er meningsløst for oss praktikere å delta i prosjekter som kun fokuserer på teoretiske tilnærminger til læring og vurdering".

I det tredje steget tematiserte jeg de meningsfulle aspektene i datamaterialet ved å identifisere fellesnevnere mellom dem, eksempelvis om de var knyttet til spesifikke fag, yrker eller aktører. De meningsfulle aspektene utgjorde åtte ulike tema. Disse beskriver ulike forutsetninger for at utviklingsarbeid i vurdering skal oppleves som meningsfullt for yrkesfaglærerne. Den videre analysen tar utgangpunkt $i$ at utviklingsarbeid må 1) være rettet mot yrkesfagenes særegenheter, 2) være yrkesrelevant, 3) ta utgangspunkt i praksisnære begrep, teorier og metoder, 4) gi profesjonell støtte, 5) legge til rette for samarbeid, 6) anerkjenne yrkesfaglige tilnærminger til valide vurderingspraksiser, 7) utfordre egen vurderingskompetanse, og 8) bidra til læring.

I det fjerde steget transkriberte jeg fokusgruppeintervjuene ordrett, leste og gjenleste den transkriberte teksten og sorterte datamaterialet etter de samme åtte temaene som feltdataene. Temaene favner bredt og ivaretar innholdet $i$ både fokusgruppeintervjuene og feltnotatene. I det femte steget samlet jeg de åtte temaene i tre overordnede kategorier. Disse utgjør studiens hovedfunn.

\section{Funn og drøfting}

Studien viser at utviklingsarbeid knyttet til kompetanseutvikling i vurdering må 1) ha yrkesfaglig relevans, 2) ivareta yrkesfaglige perspektiver på validitet og 3) foregå i en endrings- og utviklingsorientert kultur, dersom yrkesfaglæreres skal oppleve det som meningsfullt å delta. Tabell 4 illustrer hvordan de tre hovedfunnene har vokst frem av de åtte temaene i innholdsanalysen. 
One size fits nobody

Tabell 4. Oversikt over hovedfunn.

\begin{tabular}{|c|c|c|}
\hline $\begin{array}{l}\text { Overordnede } \\
\text { kategorier: }\end{array}$ & Tema fra innholdsanalysen & Eksempel fra datamaterialet \\
\hline $\begin{array}{l}\text { 1. Utviklings- } \\
\text { arbeid } i \text { vurde- } \\
\text { ring må ha yrkes- } \\
\text { faglig relevans }\end{array}$ & $\begin{array}{l}\text { 1) yrkesfagenes særegenheter, 2) } \\
\text { yrkesrelevans, 3) praksisnæe be- } \\
\text { grep, teorier, og metoder } \\
\text { Disse temaene viser til yrkesfaglæ- } \\
\text { reres fagspesifikke kunnskap og } \\
\text { ferdigheter, samt hvordan denne } \\
\text { kompetansen brukes for å skape } \\
\text { relevant opplæring og vurdering. }\end{array}$ & $\begin{array}{l}\text { "En kokk og en tømrer trenger } \\
\text { ikke den samme kompetansen i ar- } \\
\text { beidslivet. Det sier seg selv av yr- } \\
\text { kesfaglærere heller ikke kan dras } \\
\text { under en kam i utviklingsprosjek- } \\
\text { ter. De må få utvikle vurderings- } \\
\text { praksiser som er relevant for yr- } \\
\text { kesfaget de underviser i." } \\
\text { Fokusgruppeintervju gr. } 6 \text {, } \\
\text { restaurant- og matfag }\end{array}$ \\
\hline $\begin{array}{l}\text { 2. Utviklings- } \\
\text { arbeid i vurde- } \\
\text { ring må ivareta } \\
\text { yrkesfaglige per- } \\
\text { spektiv på vali- } \\
\text { ditet }\end{array}$ & $\begin{array}{l}\text { 2) yrkesrelevans, 3) praksisnære } \\
\text { begrep, teorier, og metoder 6) vali- } \\
\text { ditet vurderingspraksiser, 7) vur- } \\
\text { deringskompetanse } \\
\text { Disse temaene viser til yrkesfaglæ- } \\
\text { rernes antakelser om hva som er } \\
\text { valid vurdering i sine respektive } \\
\text { fag. }\end{array}$ & $\begin{array}{l}\text { "Vurdering i skolen handler om } \\
\text { skriftlig dokumentasjon. For å } \\
\text { skaffe dokumentasjon får vi ele- } \\
\text { vene til å skrive logg og rapporter, } \\
\text { eller ha fremlegg. Det finnes ikke } \\
\text { verbalspråk som kan beskrive alle } \\
\text { dimensjonene i et praktisk yrke. } \\
\text { Det er urettferdig at elevene skal } \\
\text { vurderes på grunnlag av hva de } \\
\text { skriver når vi vet at de ikke kan ut- } \\
\text { rykke kompetansene sin skriftlig." } \\
\text { Feltnotater gr. 3, naturbruk }\end{array}$ \\
\hline $\begin{array}{l}\text { 3. Utviklings- } \\
\text { arbeid i vurde- } \\
\text { ring må foregå } i \\
\text { en endrings- og } \\
\text { utviklingsorien- } \\
\text { tert kultur }\end{array}$ & $\begin{array}{l}\text { 4) profesjonell støtte, 5) samar- } \\
\text { beid, 7) vurderingskompetanse, } \\
\text { 8) læring } \\
\text { Disse temaene viser til emosjonelle } \\
\text { og sosiale aspekter ved læreres } \\
\text { profesjonsutvikling. }\end{array}$ & $\begin{array}{l}\text { "Det er viktig at fagene våre og vi } \\
\text { som fagfolk anerkjennes i skolen. } \\
\text { Det må være kultur for å lære gjen- } \\
\text { nom praksis, også for oss lærere. } \\
\text { Det oppleves som lite meningsfullt } \\
\text { å delta i utviklingsprosjekter der- } \\
\text { som vi skal presses inn i akade- } \\
\text { miske rammer som ikke passer fa- } \\
\text { gene eller elevene våre." } \\
\text { Fokusgruppeintervju gr. 2, bygg- og } \\
\text { anleggsfag }\end{array}$ \\
\hline
\end{tabular}

I teksten som følger utdyper og drøfter jeg de tre hovedfunnene. Jeg benytter forkortelsene BA for bygg- og anleggsfag, NAT for naturbruk og RM for restaurant- og matfag. Alle referanser til datamaterialet er nummerert fra 1 til 9 for å vise til de respektive lærergruppene. 


\section{Utviklingsarbeid i vurdering må ha yrkesfaglig relevans}

Yrkesfaglæreres vurderingspraksiser skal sikre kompetente fagarbeidere til en rekke yrker (Kemmis \& Green, 2013; Robson mfl., 2004). Deltakerne er derfor opptatt av at arbeidet de legger ned i utviklingsarbeid må oppleves som relevant, samt være overførbart til undervisnings- og vurderingsarbeidet de gjør i praksis. Lærergruppene forteller at utviklingsprosjekter må "fokusere på de respektive yrkesfagenes særegenheter", "ta hensyn til yrkesfaglærernes behov" og "komme yrkesfagelevene til gode" (feltnotater gr. 2 BA, gr. 7 BA og gr. 8 NAT). Likevel opplever deltakerne at yrkesfaglige interesser og tradisjoner blir nedprioritert i skolen, og kobler det til at utdanningspolitikere, skoleeiere og -ledere ikke nødvendigvis har kunnskap om yrkesfaglige kunnskapstradisjoner eller vet hva slags kompetanse som er relevant i ulike yrkesfaglige sektorer. Yrkesfaglærerne reflekterer imidlertid tilsynelatende lite over sin egen kunnskap om skolen og havner lett på "krigsstien og går i forsvarsposisjon ovenfor eget yrkesfag" (intervju gr. 4 NAT), i diskusjoner om kompetanseutvikling i skolekontekst.

Deltakerne finner det meningsfullt å inkludere bedrifter i eget kompetanseutviklingsarbeid. Under en samtale i planleggingsfasen forteller gruppe 2, BA, at "Bedriftene er en ressurs i utviklingsarbeid fordi de er tidlig ute med å kjøpe inn og teste ut nytt utstyr, prøve ut nye metoder og drive faglig utvikling blant ansatte". Flere lærergrupper poengterer at yrkesfagene er i konstant endring som følge av teknologiske nyvinninger og økonomiske svingninger i det globale markedet, og at de må ut i bedrift for å utvikle sin kunnskap om hva elevene skal lære, og hva de skal vektlegge når de vurderer elevenes yrkeskompetanse (Aspøy mfl., 2017; Aamodt mfl., 2016). Yrkesfaglærerne opplever imidlertid at skolen uttrykker liten interesse for eller setter av ressurser til å styrke skole-bedriftssamarbeid, og at de kjemper som et system som ikke deler deres oppfatning av hva som er viktig for at de skal utvikle relevant vurderingskompetanse både som fagarbeidere og lærere.

Ulike aktørers forståelse av relevansbegrepet er spenningsskapende faktor i utviklingsarbeid. Det er mange parter (utdanningspolitikere, skoleeiere, skoleledere, yrkesfaglige sektorer/bedrifter, lærere og elever) involvert, og disse har ulike oppfatninger av hva som er relevant opplæring og vurdering. Lærergruppene drøfter relevansbegrepet og forteller at relevans må ses i lys av kontekst, og at praksiserfaring og relevans henger tett sammen. "Aktør som skal uttale seg om relevans i yrkesfag må ha erfaring fra yrket, først da oppleves det som oppriktig" sier en lærergruppe (feltnotater, gr. 6 RM). Riktignok er deltakerne opptatt av at de jobber i skolen og at de må forholde seg til skolens styringsdokumenter, men gruppene snakker stadig om at de ikke har tillitt til at skolen ivaretar yrkesfaglige interesser, hverken på daglig basis eller i utviklingsarbeid.

Relevansbegrepet kan koples til faglig autonomi. Yrkesfaglærernes språkbruk avslører at de opplever at satte rammer for utviklingsarbeid i regi av skolen kan utfordre fagenes status og egenart. De bruker uttrykk som "one size fits nobody" 
og liknende metaforer for å understreke at deres respektive fag og deres behov for kompetanseutvikling ikke kan "settes i samme bås" eller "passe i samme form" som andre fag. "One size"-metaforen er ifølge flere lærere en passende beskrivelse på utviklingsarbeid som skal favne en hel skole med ulike fag og kulturer. "Et plagg i one size vil passe bedre til noen enn til andre. Er en genser for stor, kan du brette opp ermene. Er den for liten, blir det straks verre" forteller en BA-lærere i gruppe 2 under er samtale i planleggingsfasen. "Det er fryktelig demotiverende å aldri få utdelt noe som passer" sier en annen i samme gruppe. Lærerne anser seg selv som kreative og løsningsorienterte, men er tydelige på at de føler seg nedprioritert.

Yrkesfaglærerne er kritiske til det de opplever som et "kunnskapshierarki" i skolen. De har inntrykk av at skolen verdsetter akademisk og abstrakt kunnskap høyere enn den praktiske, tause og erfaringsbaserte kunnskapen de selv representerer. Flere av lærerne mener dette kommer spesielt til syne gjennom skolens fokus på skriftlige vurderingspraksiser.

\footnotetext{
Det virker ikke som om skolen og politikerne bryr seg om den vurderingen vi gjør når elevene jobber praktisk i verkstedet, de bryr seg kun om det som er skriftliggjort, dokumentert og arkivert. (Feltnotater gr. $7 \mathrm{BA}$ )

Det er et enormt fokus på skriftliggjøring av mål og kriterier, og ikke mist dokumentasjon av læring, men det er jo så mye vi ikke greier å skrive om, både fordi vi ikke helt har språk til å beskrive praktisk kunnskap, men også fordi at mye av det praktiske, det tause, ikke lar seg beskrive. (Intervju gr. 5 RM)
}

Sitatene viser at lærerne opplever at skolens hierarkisering av vurderingspraksiser undertrykker yrkesfagenes tause natur og svekker tilliten yrkesfaglærerens dømmekraft i undervisnings- og vurderingsøyemed.

Yrkesfaglærere er, som nevnt innledningsvis, både er fagarbeidere og lærere (Fejes \& Köpsén, 2014; Kemmis \& Green, 2013; Köpsén, 2014). Funn i denne studien viser at yrkesfaglærere må oppleve kompetanseutviklingsarbeid som relevant $\mathrm{i}$ både skole- og arbeidslivskontekst dersom det skal være meningsfullt for dem å delta. Organisatoriske, faglige og sosiokulturelle forskjeller (DeLuca, 2012; Looney mfl., 2018; Xu \& Brown, 2016), eksempelvis i vurderingspraksiser i skole og på arbeidsplass, kan gi motstridende signaler om hva som oppleves som relevant og ikke. Det kan føre til at yrkesfaglærere opplever at skole og utdanningspolitikk ikke tar høyde for at deres vurderingskompetanse er farget av deres fortid som fagarbeidere (Aspøy mfl., 2017; Aamodt mfl., 2016). Det er imidlertid viktig å stille spørsmål ved hvorvidt yrkesfaglærere tidvis kan være er så farget av sin yrkesbakgrunn at de har vanskeligheter med å se at de er del av skolen som faglig og sosiokulturell organisasjon, og at deres vurderingsarbeid favner videre enn å kvalifisere elever for fremtidig yrkesutøvelse. 
Utviklingsarbeid $\mathbf{i}$ vurdering må ivareta yrkesfaglige perspektiv på validitet $\mathbf{i}$ vurdering av yrkeskompetanse

Lærere må ha bred kunnskap om vurdering og kunne anvende denne i praksis for å innhente valid informasjon om elevers kompetanse (Popham, 2009; Stiggins, 1995; Xu \& Brown, 2016). Yrkesfaglærerne er derfor opptatt av at utviklingsarbeid i vurdering må anerkjenne yrkesfaglige metoder (observasjon, veiledning, utprøving, vurdering av prosesser og produkter) for innsamling av data om elevers læring, også i skolekontekst. Flere av lærerne poengterer at dersom de skal engasjere seg i kompetanseutviklingsarbeid i vurdering må de få arbeide med å utvikle vurderingspraksiser som gir valid informasjon om yrkesfagelevers læ ring, og ikke "bare omformulere mål og kriterier for å lage skjema og rubrikker" (feltnotater, gr. 9 RM). Lærerne er riktignok opptatt av at det må være visse vurderingsstandarder for å sikre yrkessertifisering, men kritiserer skolen for å basere "bevis på læring" nesten utelukkende på skriftlige, standardiserte kompetansemål og innsamlingsmetoder som tekstoppgaver, prøver og fremlegg (feltnotater gr. 4 NAT).

Deltakerne finner det meningsfullt å utforske vurderingspraksiser som kan gjenspeile elevers yrkeskompetanse og gi valide data om hvorvidt de er kompetente nok til å møte arbeidslivet. Yrkesfaglærerne opplever imidlertid at deres tilnærming til vurdering ikke nødvendigvis svarer til det de antar er skolens forventning til gode vurderingspraksiser. I et fokusgruppeintervju forteller en lærer om hvordan han opplever skolens holdning til vurdering:

\footnotetext{
Jeg føler at skolen er så opptatt av at alt skal måles og dokumenteres. Det fungerer ikke sånn i arbeidslivet, man skriver ikke ned alt man lærer til enhver tid. Mye av det man lærer setter seg i hendene, i kroppen. Ofte vet man ikke hva man har lært før man faktisk gjør noe i praksis og skjønner at man kan det. (Fokusgruppeintervju gr. 2 BA)
}

Videre forteller lærerne i fokusgruppa at de opplever avstand mellom sin egen og skolens oppfatning av hvilke vurderingspraksiser som gir valid informasjon om elevers yrkeskompetanse. Felles forståelse for praksiser er ansett som et premiss for at kompetanseutvikling skal finne sted, og opplevelsen av å ikke dele oppfatning med "majoriteten" kan gi en følelse av å ikke bli anerkjent (CochranSmith \& Lytle, 2009; Eggen, 2011; Engh, 2011). Lærerne avslører imidlertid at de holder sine oppfatninger om eksempelvis vurdering for seg selv, og at de ikke fronter sin forståelse for pedagogiske eller yrkesdidaktiske konsepter for skoleledelsen eller for kolleger utenfor eget fagfelt.

Deltakerne ønsker å utarbeide valide vurderingspraksiser med tydelig relevans for fremtidig yrkesutøvelse. Yrkesfagene forfekter ofte et økologisk perspektiv på validitet, hvor vurderinger kun anses valide dersom aktiviteten eller ferdigheten som vurderes kan overføres fra en situert læringssituasjon til virkeligheten, eksempelvis praktisk yrkesutøvelse (Lewkowicz, 2001; Moss, 2013; Schmuckler, 2001). I tillegg kobles ofte yrkesfagene til utvidet validitetsbegrep 
som tar høyde for den sosiale og kulturelle sammenhengen vurderingen foregår i (Kane, 2015; Messick, 1992; Moss mfl., 2006). Forskning viser også at vurdering av yrkeskompetanse bør foregå i autentiske omgivelser (Aarkrog \& Wahlgren, 2015; Gills \& Bateman, 1999; Räisänen \& Räkköläinen, 2014). Dette er et perspektiv på vurdering som skiller seg fra etablerte vurderingskulturer i skolen der elever prøves i akademiske ferdigheter uten tydelig forbindelse til et praksisfelt.

Utviklingsarbeid er ifølge deltakerne meningsfullt når de kan ta utgangspunkt i yrkesfaglige læringstradisjoner, der taus kunnskapsoverføring gjennom mesterlære og ulike modeller for ferdighetstilegnelse står sentralt (Dewey, 1916; Dreyfus \& Dreyfus, 1986; Polanyi, 1966; Sennett, 2008). I eksempelet nedenfor, hentet fra feltnotater fra analysefasen, diskuterer en lærergruppe hvordan de kan samle valid informasjon om elevers kompetanse om smak:

\begin{abstract}
Lærerne diskuterer hvordan de skal vurdere elevenes evne til å smake seg til balanse mellom syre, salt og sukker når de lager mat, på en valid måte. Ifølge gruppa er det mulig å sette ord på hva en matvare smaker, samt vurdere hvorvidt ulike smaker komplementerer hverandre og hvorfor, men de poengterer at det er en utviklingsprosess som tar tid. Det kreves bevissthet om eget smaksregister for å vurdere smak. Ifølge lærerne har ikke elevene nok erfaring til å snakke om slike yrkesspesifikke ferdigheter. Vurdering må derfor ha form som veiledning dersom elevene skal lære. "Vi kan smake og finne referanser sammen" sier en av lærerne. Resten av gruppa er enige i at dette er en god måte å vurdere elevenes kunnskap om smak på, både fordi de lærer om smak, men også fordi de lærer en teknikk de kan bruke sammen med fremtidige kolleger for å fortsette å utvikle sine kunnskaper om smak. Lærerne forteller at elevene ikke er utlært når de er ferdige på skolen. De skal først ut i lære og deretter ut i et arbeidsliv i konstant utvikling. De må derfor lære metoder for kompetanseutvikling som oppleves som valide og relevante for deres fremtidige yrkesutøvelse. (Feltnotater gr. 9 RM)
\end{abstract}

Denne metoden for vurdering av smak er ifølge lærerne valid fordi elevene kan overføre den situerte vurderingssituasjonen til praktisk yrkesutøvelse.

Yrkesfaglærerne kritiserer skolens skriftlige "skjemavelde" (intervju gr. 2 BA). Deltakerne bruker argumenterer som at "Yrkeskompetanse passer ikke inn i et skjema eller en rubrikk", "Vi får ikke frem det elevene er gode på" og "Læreplanen er ofte et hinder i opplæringa" (intervju gr. 4 NAT). Yrkesfaglærerne begrunner påstandene med at skriftlige vurderingspraksiser ikke egner seg for vurdering av yrkeskompetanse ettersom "mye av datagrunnlaget bare finnes i praksis" og at man "må tolke det man observerer der og da for å hjelpe elevene videre" (feltnotater gr. 3 NAT). Flere av deltakerne antyder at skriftliggjøring kan være en trussel mot validitet i vurdering av yrkeskompetanse ettersom informasjon om elevenes læring vil gå tapt når de transformerer beviser samlet gjennom observasjon av praktisk utprøving, veiledning og refleksjon, til karakterer basert på standardiserte mål og kriterier. Riktignok har de fleste bransjer skriftlige standarder (HMS-rutiner, opplæringsmanualer, kontrollsystemer, sjekklister) og benytter verbalspråk for å praktisere yrkesutøvelse, men lærerne trekker frem spenningene mellom skriftkulturene i skole og arbeidsliv fremfor likhetene. 
Lærernes motstand mot skriftliggjøring av kompetanse har trolig en mer sammensatt forklaring enn at skriftlig arbeid kan mangle yrkesfaglig relevans eller ikke gi valide data om elevers læring i praktiske fag. Deltakerne har inntrykk av at utviklingsprosjekter ofte skal resultere i skriftlige produkter som "beviser" kompetanseutvikling. Det får dem umiddelbart til å "slå ut piggene" for å sitere en lærer i gruppe 1, BA. Gruppa forklarer at de, på samme måte som elevene, ikke får vist hva de kan når kompetansen må uttrykkes verbalt, spesielt skriftlig. "Språket kommer til kort når de skal beskrive både min egen og elevenes tause yrkeskompetanse" sier en lærer (feltnotater, gr. 7 NAT). Andre utsagn som "jeg får ikke med meg det jeg leser fordi teorien er så fjern fra praksis" og "jeg føler meg usikker når jeg må dele det jeg skriver fordi jeg vet jeg at skrivekompetansen min får meg til å se dum ut på papiret" (intervju med gr. 2 BA og 4 NAT) indikerer at lærerne tidvis tviler på egen lese- og skrivekompetanse.

Flere av deltakerne sier "det er flaut å spørre om hjelp" og at de unngår å snakke med kolleger og ledere om behovet for språklig utvikling fordi "alle forventer at en lærer har gode lese- og skriveferdigheter" (intervju, gr. 3 NAT). Videre forteller de at de heller opprettholder "imaget" om at lese- og skrivekompetanse ikke er avgjørende for å bli en god fagarbeider, og avfeier problematikken med utsagn om at taus kunnskap ikke kan uttrykkes verbalt og at skriftlige, standardiserte mål og kriterier ikke gir valid informasjon om yrkesfagelevers læring. Disse funnene antyder likevel at yrkesfaglærere ønsker å utvikle et verbalspråk som lar dem delta i diskusjoner om eksempelvis vurdering. Deltakerne antyder at det ikke er nok fokus på hvordan de skal mestre språklige og kulturelle barrierer mellom yrkesliv og skole i yrkesfaglærerutdanningen, og at dette er spesielt fremtredende når de deltar i utviklingsarbeid som involverer hele skoleorganisasjonen de arbeider i. Det er likevel behov for at skolen anerkjenner at det er svært utfordrende for yrkesfaglærere å sette ord på yrkeskompetanse, og legger til rette for at de opplever mestring i utviklingsarbeid.

\section{Utviklingsarbeid i vurdering må foregå i en endrings- og utviklingsorientert kultur}

Lærere har behov for trygge rammer og profesjonell annerkjennelse når de skal utfordre sin egen kompetanse. "Det må være rom for å prøve og feile uten at man føler seg helt mislykket" sier en av deltakerne (feltnotater, gr. 8 RM). En annen deltaker forteller at "dersom ledelsen ikke er interessert i det vi gjør, eller backer oss opp når vi har lyst til å prøve ut nye ting, oppleves det som helt meningsløst å investere masse tid og krefter i utviklingsarbeid" (intervju gr. 1 BA). Lærerne opplever at faglig og personlig støtte fra kolleger og ledere har stor betydning for hvorvidt de engasjerer seg i utviklingsarbeid eller ikke.

Trygghet, støtte og anerkjennelse trekkes frem som viktige premisser for læreres profesjonelle utvikling i skoleutviklingsforskning (Cochran-Smith \& Lytle, 2009; Eggen, 2011; Engh, 2011). Yrkesfaglærerne har imidlertid erfart at de ikke 
nødvendigvis får den støtten de har behov for når skolen setter i gang utviklingsprosjekter. "Vi får bare beskjed om at vi bare må tilpasse prosjektene våre sånn at det passer til yrkesfagene, men det er ingen som hjelper oss med det eller følger opp det vi gjør" (feltnotater gr. 9 RM). Deltakerne verdsetter å få frihet til å forme utviklingsprosjekter selv, men sier at det er viktig at ledelsen følger opp og stiller spørsmål ved valgene de tar dersom profesjonell utvikling skal vinne sted. Lærerne forteller riktignok at de "greier seg på egenhånd", men at de opplever utviklingsarbeid "som langt mer givende" dersom noen utenfor eget fagfelt viser interesse arbeidet (feltnotater gr. 7 BA). Deltakerne poengterer at skoleledelsen mangler kompetanse på yrkesfag, men at det ikke er god nok grunn til å presse yrkesfagene $\mathrm{i}$ " one size fits nobody-modeller" som skal passe alle fag, eller overlate dem til seg selv.

Utviklingsarbeid må ifølge deltakerne være ønsket av aktørene som er involvert. Flere lærere forteller at det er krevende å være pådriver for endring og utvikling dersom involverte parter ikke er samarbeidsorienterte eller ønsker endring. En gruppe trekker frem et eksempel fra vurderingssamarbeid med bedrift:
Vi ser ofte at elevene kommer tilbake fra praksis i bedrift med mangelfull doku- mentasjon på hva de har lært. Ofte har de ikke fått noen dokumentasjon i det hele. Vi er jo ikke til stede i denne perioden, annet enn ett og annet kort besøk, og er av- hengig av tilbakemeldingene vi får fra bedriften. Vi bruker enormt mye tid på å ut- arbeide enkle skjema bedriften kan benytte, men opplever at det stadig blir glemt eller at de ikke ser poenget med å bruke dem. Vi opplever også at bedriften bare krysser av for høy måloppnåelse eller toppkarakter, men da viser det seg ofte at vurderingen er gjort på grunnlag av at eleven eksempelvis har møtt opp til tiden eller utført svært enkle oppgaver som å skrelle poteter. Da forventer elevene å få toppkarakterer på skolen også, men de forstår ikke at læringsmålene på skolen er mer omfattende. (Intervju gr. 5, RM)

Gruppa sier de har brukt mye av tiden som har vært avsatt til ulike utviklingsprosjekter til å utvikle metoder og verktøy (sjekklister, rubrikker med kriterier for måloppnåelse, enkle skjema for tilbakemelding) for å samle valide data om elevers læring ute i bedrift. Lærerne forteller imidlertid at dette arbeidet ikke nødvendigvis har gitt ønskede resultater, fordi skjemaene ikke ble brukt riktig, eller ikke ble benyttet i det hele tatt. Det kan også tenkes at bedriftene ikke opplever skjemaene elevene har med seg fra skolen som egnet for å vurdere kompetansen de opparbeider seg ute i bedrift. Videre antyder gruppa at bedriftene de samarbeider med kan oppleves som lite samarbeidsvillige og utviklingsorienterte når de introduserer nye metoder og verktøy for vurdering. Enkelte går så langt at de kritiserer enkelte bedrifter for å neglisjere sitt samfunnsansvar som opplæringsinstitusjoner og anklager dem for å kun tenke profitt, men de har også stor forståelse for at opplæring og vurdering $\mathrm{i}$ arbeidslivet ikke passer inn $\mathrm{i}$ skjema og rubrikker.

Yrkesfaglærerne opplever at de er i skvis mellom kulturer med ulike tradisjoner for læring og vurdering, og at utviklingsarbeidet de gjør ikke anerkjennes av hverken den ene eller den andre parten. "Skolen kritiserer oss for å ikke forankre 
vurderingspraksisene våre i skolekulturen og at bransjene kritiserer oss for å benytte praksisfjerne tilnærminger til vurdering" forteller en av lærergruppene (feltnotater gr. 3 NAT). Det får dem til å gå i opposisjon mot vurderingskulturen som råder både i skolen og i bransjene, "'og sette seg litt på bakbeina", for å låne et uttrykk flere lærergrupper brukte for å beskrive sin egen innstilling til utviklingsarbeid.

I fortrolige samtaler avslører flere lærere at de tidvis skylder på at skolen ikke legger til rette for yrkesrelevant kompetanseutvikling, og at de derfor trekker seg unna utviklingsprosjekter fremfor å finne gode grunner til å utfordre egen praksis. Riktignok innrømmer deltakerne at tidspress også er en avgjørende grunn til at de ikke prioriterer utviklingsarbeid. "Vi må hele tiden ta oss av elevsaker og andre arbeidsoppgaver som brenner" sier en lærer (feltnotater, gr. 3 NAT). Deltakerne forteller også at de har for mange elever, at de mangler utstyr og ikke har egnede fasiliteter for å prøve ut eksempelvis nye vurderingspraksiser. Tid regnes som en avgjørende faktor for suksessfull kompetanseutvikling i skoleutviklingsforskning (Cochran-Smith \& Lytle, 2009; Eggen, 2011; Engh, 2011). Dersom lærere har oppgaver de opplever som viktigere eller som haster, blir det utfordrende for dem å prioritere utviklingsarbeid. Deltakerne i studien forteller at de gjerne ønsker å utvikle seg, både som fagarbeidere og lærere, men at arbeidshverdagen ikke tillater dem å bruke tid på egen utvikling.

\section{Oppsummering av funn}

Studien viser at kompetanseutviklingsprosjekter med fokus på vurdering må ha yrkesfaglig relevans, ivareta yrkesfaglige perspektiver på validitet i vurdering av yrkeskompetanse og foregå i en endrings- og utviklingsorientert kultur dersom yrkesfaglærere skal oppleve det som meningsfullt å delta. Samtidig viser funnene at yrkesfaglærerne i studien ikke nødvendigvis opplever at skolen ivaretar disse behovene i utviklingsarbeid. Kort oppsummert opplever deltakerne at avstanden mellom vurderingskulturer (holdninger, kunnskapssyn, språk, verdier, tradisjoner) i skolen og i yrkesfaglige sektorer, i dette tilfellet, bygg- og anleggsteknikk, naturbruk, restaurant- og matfag, er stor, og at det gjør det utfordrede å skape felles referanserammer for hva som oppfattes som gode vurderingspraksiser, samt reflektere over hva om gjør dem gode. Videre er deltakerne opptatt av at deres egen profesjonsutvikling skal komme både deres respektive fagfelt og elevene til gode, samt at det kunnskapssynet og de tradisjonene for læring og vurdering de representerer, blir anerkjent i skolekontekst. Samtidig avslører funn i studien at lærerne selv gjør lite for å fronte egne behov, og at de tidvis er i opposisjon mot det de opplever som et akademisk kunnskapshierarki i skolen. 


\section{Implikasjoner}

Yrkesfaglæreres kompetanseutviklingsbehov, spesielt innenfor vurdering, er underkommunisert i forskning og policy (Aspøy mfl., 2017; Gjerustad \& Waagene, 2015; Aamodt mfl., 2016). Denne studien er et kunnskapsbidrag til forskning på vurdering i yrkesfag og på yrkesfaglæreres vurderingskompetanse. Den spør "Hvilke aspekter ved kompetanseutviklingsprosjekter i videregående skole opplever yrkesfaglærere som meningsfulle for utvikling av egen vurderingskompetanse?". Videre drøfter studien hvilke implikasjoner hovedfunnene "utviklingsarbeid må 1) ha yrkesfaglig relevans, 2) ivareta yrkesfaglige perspektiv på validitet $i$ vurdering av yrkeskompetanse og 3) foregå i en endrings- og utviklingsorientert kultur dersom yrkesfaglærere skal finne det meningsfullt å delta" har for policy, forskning og praksis.

Med utvikling av vurderingskompetanse som bakteppe, antyder studien at spenninger i utviklingsarbeid oppstår fordi skole og bedrift har ulikt syn på hensikten med fag- og yrkesopplæring, forskjellig syn på kunnskap, ulike kulturer for læring og vurdering og tidvis motstridende syn på hva som er relevante og valide vurderingspraksiser. Det forventes imidlertid at yrkesfaglærere med sin doble profesjon skal være brobyggere mellom skolen og arbeidslivet (Fejes \& Köpsén, 2014; Kemmis \& Green, 2013; Köpsén, 2014), samt håndtere organisatoriske, faglige og sosio-kulturelle spenninger som oppstår i kontekst av utviklingsarbeid. Likevel møter yrkesfaglærerne et kunnskapshierarki skolen, der yrkesfagenes autonomi, samt deres stolte fagarbeideridentitet ikke blir anerkjent $\mathrm{i}$ den grad de har behov for.

Det er krevende for yrkesfaglærere å delta i kompetanseutviklingsarbeid som ikke oppleves som relevante for deres egen utvikling eller som kommer deres elever eller respektive fagfelt til gode. Det er nødvendig å anerkjenne at yrkesfaglærere, de ulike yrkesfaglige studieretningene og de mange yrkene de kvalifiserer til, har ulike behov og ikke nødvendigvis passer inn $\mathrm{i}$ "one size fits nobody"-modeller for utviklingsarbeid. Selv om forskningsrapporter (Aspøy mfl., 2017; Gjerustad \& Waagene, 2015; Aamodt mfl., 2016) viser at yrkesfaglærere har andre behov, eksempelvis holde seg faglig oppdatert gjennom samarbeid med bedrift, sier de lite om hvordan yrkesfaglærer skal håndtere og operasjonalisere policy.

Det er nødvendig å inkludere yrkesfaglærere i diskusjoner om utviklingsarbeid. Utdanningspolicy tar tidvis lite hensyn til yrkesfagenes autonomi og kan gi inntrykk av at yrkesfaglærere har de samme kompetanseutviklingsbehovene som lærere i tradisjonelle, akademiske skolefag. Språklige og kulturelle barrierer mellom yrkesfag, utdanningspolicy og forskning gjør det imidlertid utfordrende for yrkesfaglærere å ta del i debatter, spesielt om vurdering. Vurderingslitteratur argumenterer eksempelvis for at læreres erfaringer med og antakelser om vurdering er betydningsfulle for hvordan de forstår vurderingsterminologi og 
teoretiske konsepter, samt hva de oppfatter som relevant og valid vurdering (DeLuca \& Klinger, 2010; DeLuca mfl., 2019; Looney mfl., 2018; Taylor, 2009; Xu \& Brown, 2016). Yrkesfaglæreres vurderingskompetanse er forankret i arbeidslivskontekst og yrkesspesifikke, ofte tause tradisjoner for læring og vurdering (Kemmis \& Green, 2013). Taus, erfaringsbasert kunnskap lar seg ikke nødvendigvis oversette til skriftlige mål og kriterier som passer i skolekontekst. Ettersom yrkesfaglærerne selv kommer fra "tause" fagfelt, kan skolens vurderingskultur og vurderingsterminologi oppleves som fjern fra egen praksis og forståelseshorisont.

Yrkesfaglærere har behov for verktøy som gjør dem forhandlingsdyktige når de havner i skvis mellom skolens og arbeidslivets interesser i fag- og yrkesopp-

læringen. Å overkomme språklige og kulturelle barrierer, samt anerkjenne ulike kunnskapssyn, synes å være en inngang til brobyggingsarbeid, ettersom felles forståelse for språk, kultur og kunnskap er med på å styrke vurderingsfellesskaper i skolen (Cochran-Smith \& Lytle, 2009; Eggen, 2011; Engh, 2011). Dette er imidlertid ikke et arbeid yrkesfaglærere kan gjøre alene. Aktører som lærerutdanningsinstitusjoner, skoleeiere og yrkesfaglige sektorer må på banen for å bidra til at utdanningstilbudene yrkesfaglærere får, imøtekommer behovene de har både som fagarbeidere og lærere, samt styrker deres rolle som forhandlere mellom skole og arbeidsliv. Riktignok må også yrkesfaglærerne selv engasjere seg, for dersom de forblir tause er det stor risiko at deres doble kompetanseutviklingsbehov forblir underkommunisert.

\section{Om forfatteren}

Julie Klovholt Leonardsen er doktorgradsstipendiat ved NTNU - Norges tekniske og naturvitenskaplige universitet, institutt for lærerutdanning, hvor hun underviser ved den 3-årige yrkesfaglærerutdanningen, samt masterutdanningen innenfor yrkesdidaktikk. Hun har yrkesfaglig utdanning innen restaurant- og matfag og lektorutdanning med master i språkfag, samt en master i lærerprofesjon og yrkesutøvelse. Hun har praksiserfaring både fra yrkesfaglig sektor og videregående skole. Hennes forskningsinteresser er yrkesfaglæreres doble profesjon, med særlig vekt på vurdering og vurderingskompetanse. 


\section{Referanser}

Andersson, P. \& Köpsén, S. (2015). Continuing professional development of vocational teachers: Participation in a Swedish national initiative. Empirical Research in Vocational Education and Training, 7(1). https:/ / doi.org/10.1186/s40461-015-0019-3

Aspøy, T. M., Skinnarland, S. \& Tønder, A. H. (2017). Yrkesfaglærerens kompetanse. FAFO-rapport 2017:11. https://www.fafo.no/images/pub/2017/20619.pdf

Assessment Reform Group. (2002). Assessment for learning: 10 principles. University of Cambridge.

Black, P. \& William, D. (1998). Inside the black box: Raising standards through classroom assessment. Phi Delta Kappan, 80(2), 139-148.

https:/ / doi.org/10.1177/003172171009200119

Black, P. \& William, D. (2009). Developing the theory of formative assessment. Educational Assessment Evaluation and Accountability, 21(1), 5-33. https:/ / doi.org/10.1007/s11092-008-9068-5

Brown, G. T. L. (2004). Teachers' conceptions of assessment: Implications for policy and professional development. Assessment in Education: Principles, Policy $\mathcal{E}$ Practice, 11(3), 301-318. https:/ / doi.org/10.1080/0969594042000304609

Cochran-Smith, M. \& Lytle, S. L. (2009). Inquiry as stance: Practitioner research for the next generation. Teachers College Press.

Creswell, J. W. (2007). Qualitative inquiry and research design: Choosing among five traditions (2. utgave). SAGE.

DeLuca, C., Chavez, T. \& Cao, C. (2013). Establishing a foundation for valid teacher judgement on student learning: The role of pre-service assessment education. Assessment in Education: Principles, Policy E Practice, 20(1), 107-126. https:/ / doi.org/10.1080/0969594X.2012.668870

DeLuca, C. \& Klinger, D. A. (2010). Assessment literacy development: Identifying gaps in teacher candidates' learning. Assessment in Education: Principles, Policy E Practice, 17(4), 419-438. https:/ / doi.org/10.1080/0969594X.2010.516643

DeLuca, C. (2012). Preparing teachers for the age of accountability: Toward a framework for assessment education. Action in Teacher Education, 34(5-6), 576591. https:// doi.org/10.1080/01626620.2012.730347

DeLuca, C, Coombs, A., MacGregor, S. \& Rasooli, A. (2019). Toward a differential and situated view of assessment literacy: Studying teachers' responses to classroom assessment scenarios. Frontiers in Education, 4. https://doi.org/10.3389/feduc.2019.00094

Dewey, J. (1916). Democracy and education: An introduction to the philosophy of education. Macmillian.

Dreyfus, H. \& Dreyfus, S. (1986). Mind over machine: The power of human intuition and expertise in the era of the computer. Free Press.

Eggen, A. B. (2011). Vurdering for skoleutvikling. Gyldendal akademisk. 
Engh, R. (2011). Vurdering for læring i skolen: På vei mot en bærekraftig vurderingskultur. Høyskoleforlaget.

Fejes, A. \& Köpsén, S. (2014). Vocational teachers' identity formation through boundary crossing. Journal of Education and Work, 27(3), 265-283.

https:/ / doi.org/10.1080/13639080.2012.742181

Flyvbjerg, B. (2006). Five misunderstandings about case-study research. Qualitative Inquiry, 12(2), 219-245. https:/ / doi.org/10.1177/1077800405284363

Gills, S. \& Bateman, A. (1999). Assessing in VET: Issues of reliability and validity. Review of research. NCVER.

https://www.ncver.edu.au/research-and-statistics/publications/all-publications/assessing-in-vet-issues-of-reliability-and-validity-review-of-research

Gjerustad, G. \& Waagene, E. (2015). Spørsmål til Skole-Norge 2015: Resultater og analyser fra Utdanningsdirektoratets spørreundersøkelse blant skoler og skoleeiere NIFU-rapport 2015:19). NIFU.

Grande, S., Lyckander, R., Landro, J. \& Rokkones, K. (2014). Frem i lyset! En kartlegging av status og behov for lærerutdanning for yrkesfag. HIOA.

https:/ / www.ntnu.no/documents/150035/20502917/Fram+i+lyset!/60886d96-25e0-4ef3-b67d-a153770ef7c4

Hiim, H. (2020). Å vurdere yrkeskompetanse: Hva er yrkeskompetanse, og hvordan kan den vurderes? Nordic Journal of Vocational Education and Training, 10(3), 45-66. https:/ / doi.org/10.3384/njvet.2242-458X.2010345

Høst, H. (2015). Kvalitet $i$ fag- og yrkesopplæringen (NIFU-rapport 2015:14). NIFU. http:/ / hdl.handle.net/11250/284140

Kane, M. T. (2015). Explicating validity. Assessment in Education: Principles, Policy E Practice, 23(2), 198-211. https://doi.org/10.1080/0969594X.2015.1060192

Kemmis, R. B. \& Green, A. (2013). Vocational education and training teachers' conceptions of their pedagogy. International Journal of Training Research, 11(2), 101-121. https:// doi.org/10.5172/ijtr.2013.11.2.101

Klenowski, V. \& Wyatt-Smith, C. (2014). Assessment for education: Standards, judgement and moderation. SAGE.

Köpsén, S. (2014). How vocational teachers describe their vocational teacher identity. Journal of Vocational Education $\mathcal{E}$ Training, 66(2), 194-211. https:/ / doi.org/10.1080/13636820.2014.894554

Kvale, S., Brinkmann, S., Anderssen, T. M. \& Rygge, J. (2015). Det kvalitative forskningsintervju. Gyldendal akademisk.

Lave, J. \& Wenger, E. (1991). Situated learning: Legitimate peripheral participation. Harvard University press.

Lewkowicz, D. J. (2001). The concept of ecological validity: What are its limitations and is it bad to be invalid? Infancy, 2(4), 437-450.

https://doi.org/10.1207/S15327078IN0204_03 
Looney, A., Cumming, J., van Der Kleij, F. \& Harris, K. (2018). Reconceptualising the role of teachers as assessors: Teacher assessment identity. Assessment in Education: Principles, Policy E Practice, 25(5), 442-467.

https:/ / doi.org/10.1080/0969594X.2016.1268090

Messick, S. (1992). The interplay of evidence and consequences in the validation of performance assessments. ETS Research Report Series, 1992(1), i-42. https:/ / doi.org/10.1002/j.2333-8504.1992.tb01470.x

Moss, P. (2013). Validity in action: Lessons from studies of data use. Journal of Educational Measurement, 50(1), 91-98. www.jstor.org/stable/23353799

Moss, P. A., Girard, B. J. \& Haniford, L. C. (2006). Chapter 4: Validity in educational assessment. Review of Research in Education, 30(1), 109-162. https:/ / doi.org/10.3102/0091732X030001109

NTNU \& TRFK. (2017). Skolebasert kompetanseutvikling i vurdering (SKUV) - Kunnskapsgrunnlaget.

https:/ / www.ntnu.no/documents/1272526547/1272693899/SKUVkunnska psgrunnlag+versjon+31.01.17.pdf/67a5578e-3a26-4d05-9912-d4efa5f0a6de

Polanyi, M. (1966). The tacit dimension. Doubleday \& Co.

Popham, W. J. (2009). Assessment literacy for teachers: Faddish or fundamental? Theory into Practice, 48(1), 4-11. https:/ / doi.org/10.1080/00405840802577536

Ragin, C. C. \& Becker, H. S. (Red.). (1992). What is a case? Exploring the foundations of social inquiry. Cambridge University Press.

Räisänen, A. \& Räkköläinen, M. (2014). Assessment of learning outcomes in Finnish vocational education and training. Assessment in Education: Principles, Policy E Practice, 21(1), 109-124. https:/ / doi.org/10.1080/0969594X.2013.838938

Robson, J., Bailey, B. \& Larkin, S. (2004). Adding value: Investigating the discourse of professionalism adopted by vocational teachers in further education colleges. Journal of Education and Work, 17(2), 183-195. https:/ / doi.org/10.1080/13639080410001677392

Schmuckler, M. A. (2001). What Is ecological validity? A dimensional analysis. Infancy, 2(4), 419-436. https:// doi.org/10.1207/S15327078IN0204_02

Sennett, R. (2008). The craftsman. Yale University Press.

Stiggins, R. J. (1995). Assessment literacy for the 21st century. Phi Delta Kappan, 77(3), 238-245.

Stiggins, R. J. (1991). Relevant classroom assessment training for teachers. Educational Measurement: Issues and Practice, 10(1), 7-12. https:/ / doi.org/10.1111/j.1745-3992.1991.tb00171.x

Street, B. V. (2002). Literacy and Development: Ethnographic Perspectives (1. utgave). Routledge. https:// doi.org/10.4324/9780203468418

Sund, G., Nore, H. \& Vagle, I. (2009). Vurdering for og av læring i yrkesfag. I S. Dobson, K. Smith \& A. B. Eggen (Red.), Vurdering, prinsipper og praksis (s. 214234). Gyldendal. 
Sylte, A. L. (2014). Vurdering for yrkesrelevant opplæring. Nordic Journal of Vocational Education and Training, 4(1), 1-18.

https:/ / doi.org/10.3384/njvet.2242-458X.14v4i1a4

Taylor, L. (2009). Developing assessment literacy. Annual Review of Applied Linguistics, 29, 21-36. https:/ / doi.org/10.1017/S0267190509090035

Throndsen, I., Hopfenbeck, T. N., Lie, S. \& Dale, E. L. (22009). Bedre vurdering for læring: Rapport fra evaluering av modeller for kjennetegn på måloppnåelse i fag. Universitet i Oslo.

Xu, Y. \& Brown, G. T. L. (2016). Teacher assessment literacy in practice: A reconceptualization. Teaching and Teacher Education, 58, 149-162. https:/ / doi.org/10.1016/j.tate.2016.05.010

Aamodt, P. O., Carlsten, T. C., Caspersen, J., Grøgaard, J. B. \& Røsdal, T. (2016). Kompetanseutvikling blant yrkesfaglærere: En undersøkelse basert på OECD Teaching and Learning International Survey (TALIS) (NIFU-rapport 2016:6). https:/ / www.udir.no/globalassets/filer/tall-og-forskning/forskningsrapporter/kompetanseutvikling_blant_yrkesfaglarere.pdf

Aarkrog, V. \& Wahlgren, B. (2015). Assessment of prior learning in adult vocational education and training. International Journal for Research in Vocational Education and Training, 2(1), 39-58. https:/ / doi.org/10.13152/ijrvet.2.1.3 